\title{
УДОСКОНАЛЕННЯ ТЕХНОЛОГІЇ ОБСЛУГОВУВАННЯ ВАНТАЖОБАГАЖІВ ПРИ ЗДІЙСНЕННІ ШВИДКІСНОГО РУХУ
}

\author{
Канд. техн. наук А.Л. Обухова, магістрант С.Ю. Мар'юшкіна

\section{УСОВЕРШЕНСТВОВАНИЕ ТЕХНОЛОГИИ ОБСЛУЖИВАНИЯ ГРУЗОБАГАЖА ПРИ} \\ ВЫПОЛНЕНИИ СКОРОСТНОГО ДВИЖЕНИЯ
}

\author{
Канд. техн. наук А.Л. Обухова, магистрант Е.Ю. Марьюшкина \\ THE IMPROVEMENT OF SERVICE TECHNOLOGY CARGO-LUGGAGE WHEN \\ PERFORMING HIGH-SPEED TRAFFIC
}

\author{
Cand. of tehn. sciences A. Obukhova, master student E. Mariushkina
}

У статті висвітлено питання щзодо впровадження швидкісного руху (як приклад розвитку швидкісного руху в Україні розглядається Державне підприємство «Украӥнська залізнична швидкісна компанія») і якості обслуговування пасажсирів на залізничному транспорті України. Розглянуто один з видів послуг, який загалом надає залізничний транспорт,- ще обслуговування вантажобагажів при здійсненні швидкісного руху.

Ключові слова: пасажси, послуга, залізничний транспорт, швидкісний рух, багаж, вантажобагаж.

В статье освещены вопросы по внедрению скоростного движения (как пример развития скоростного движения в Украине рассматривается Государственное предприятие «Украинская железнодорожная скоростная компания») $и$ качества обслуживания пассажиров на железнодорожном транспорте Украины. Рассмотрен один из видов услуг, который в целом оказывает железнодорожный транспорт, - это обслуживание грузобагажей при осуществлении скоростного движения.

Ключевые слова: пассажир, услуга, железнодорожный транспорт, скоростное движение, багаж, грузобагаж.

The article covering the issue of implementation of high-speed traffic (as an example of high-speed traffic in Ukraine, considered the State Enterprise "Ukrainian-speed railway company") and the quality of passenger service on the railway transport of Ukraine. Considered one of the services, which provides rail transport in general - a cargo service in the implementation of high-speed traffic.

Keywords: passenger, services, the railway transport, high-speed traffic, luggage, cargo luggage.

Вступ. Залізничний транспорт є однією 3 важливих галузей економіки України, $\epsilon$ провідною галуззю в дорожньо-транспортному комплексі країни, який забезпечуе $82 \%$ вантажних і майже 50 \% пасажирських перевезень, здійснюваних всіма видами транспорту.

Пасажирські перевезення відіграють важливу роль в економіці України тому зі зростанням пасажиропотоку підвищується культура обслуговування пасажирів, будується новий рухомий склад підвищеного комфорту, реконструюються залізничні лінії, застосовуються нові передові технології, використовуються машин для прибирання приміщень, виконуються та удосконалюються роботи 3 багажем i вантажобагажем, оновлюється приміський парк поїздів, у такі поїзди ставлять вагони, які для більшої зручності поділяють на 3 класи. У зв'язку з тим, що Україна займає центральне положення в Європі, сучасні тенденції на ринку транспортних послуг 3 перевезення пасажирів полягають у відносному зменшенні ролі залізничного та підвищенні значення автомобільного та повітряного транспорту, необхідні заходи стосовно посилення привабливості саме залізничних перевезень для населення. Цього можна досягти через 
впровадження швидкісних магістралей, тому розпочато запровадження швидкісних ліній i комфортних послуг пасажирам [8].

Постановка проблеми. Збитковість залізничних пасажирських перевезень у всіх видах сполучень (рисунок) спонукають залізниці до пошуку нових форм співпраці 3 пасажирами через пропонування їм широкого асортименту послуг 3 підвищенням їх привабливості, що в результаті дасть зростання обсягів роботи і дохідних надходжень. Як свідчить практика, такий шлях підвищення ефективності та прибутковості пасажирських перевезень $є$ найбільш реальним, тому що підвищення вартості проїзду та надання традиційних послуг суттєво не збільшує доходи залізниць.
Становлення i розвиток ринкових відносин у державі призводить до значних змін у всіх сферах життєдіяльності суспільства. Продовжується розшарування населення за рівнем доходів, продовжує розвиватися вітчизняний бізнес, що сприяє зростанню економічних зв'язків між підприємствами, підприємцями i різноманітними структурами. Завдяки цьому зростає потреба людей у здійсненні поїздок і послугах, які пропонує залізниця з метою задоволення, перш за все, власного економічного інтересу. На сьогоднішній день значна частина пасажирів має потребу в наданні нових послуг. Основним серед них $є$ доставка пасажирів, багажу та вантажобагажу на вокзали i у пункти призначення [2].

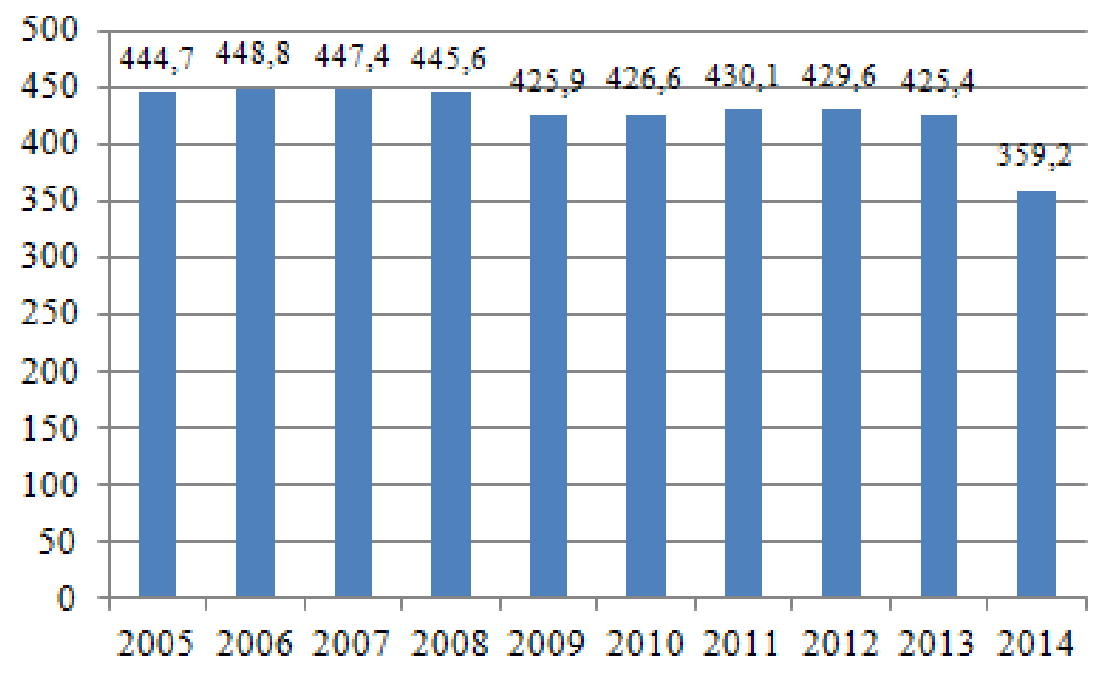

Рис. Обсяги пасажирських перевезень за 2005-2014 pp.

Аналіз останніх досліджень i публікацій. У середині XX ст. провідні вчені Радянського Союзу, такі як Б.Е. Пейзахсон, Н.І. Бещева, Н.В. Колодяжний, здійснили низку науково-дослідних і проектних робіт 3 впровадження спеціалізованих залізничних ліній для руху пасажирських поїздів зі швидкістю 250 км/год у напрямку Москва Сімферополь. До 1990 року планувалося організувати рух від 30 до 93 таких пар пасажирських поїздів. Також було встановлено, що впровадження швидкісного руху дозволить збільшити пропускну й провізну спроможність залізничних ліній, пасажиропотік i рівень комфорту для пасажирів. Усе це сприяло б підвищенню ефективності роботи залізниць. Проте через труднощі, пов'язані з необхідністю організації вантажних перевезень, обсяги яких значно збільшувались, відклали на певний час питання організації швидкісного руху.

У 2004 році консалтингова компанія «Systra» виконала дослідження для Укрзалізниці щодо можливості використання потягів зі швидкістю до 250 км/год на залізничних маршрутах Київ - Львів і Київ Одеса. Для цього було запропоновано оновити колію і сигналізацію, але лише у випадку, якщо вантажні та звичайні пасажирські перевезення будуть відведені 3 магістралі або сконцентровані в певний час дня [3]. 
Останні 10 років в Україні здійснювалися заходи з впровадження швидкісних залізничних перевезень і послуг, пов'язаних 3 ними. Для цього було ухвалено низку нормативноправових документів. Проведення в країні чемпіонату Європи 3 футболу у 2012 році значно прискорило цей процес [3].

Нормативно-правовою базою регулювання надання послуг пасажирам на Укрзалізниці $\epsilon$ «Правила перевезення пасажирів, багажу, вантажобагажу та пошти» [6].

Визначення мети i завдання дослідження. Метою даної роботи, під час впровадження та розвитку швидкісних перевезень в Україні, $є$ аналіз діяльності роботи залізниць 3 визначенням якості надання їх послуг, які надаються пасажирам на залізницях України. На сьогодні потрібно не тільки перевезти вантаж i витримати термін його доставки, але й здійснити транспортне обслуговування по різних класах якості, мінімізуючи втрати при перевезені та обслуговуванні вантажобагажів і витрати на них.

Завданням роботи $є$ дослідження створення сучасного, ефективно працюючого в ринкових умовах швидкісного пасажирського транспорту і технології обслуговування вантажобагажів i ïx значущості не тільки заради прибутку, який буде зростати не лише від обсягів перевезень, a i завдяки раціональному їх використанню [5].

Основна частина досліджень. Підготовка до впровадження швидкісного руху пасажирських поїздів в Україні тривала не один рік. У 2009 р. Кабінетом Міністрів України було схвалено Стратегію розвитку залізничного транспорту на період до 2020 р. [10]. У цьому документі визначено основні напрямки реалізації Стратегіï, а саме стосовно технічного переоснащення об'єктів інфраструктури залізниць:

- модернізація об'єктів інфраструктури залізничних ліній за напрямками Київ Коростень - Шепетівка, Київ - Полтава Харків - Донецьк, Київ -Львів, Київ Миронівка;

- забезпечення залізниць рухомим складом вітчизняного виробництва, здатним істотно підвищити техніко-технологічні показники, зокрема щодо підвищення швидкості руху вантажних поїздів до 100-120 км/год і пасажирських - до 160-200 км/год;
- удосконалення технології організації перевезень шляхом організації руху поїздів за напрямками, які будуть орієнтовані переважно на один вид перевезень (пасажирські або вантажні);

- створення системи логістики та мережі логістичних структур;

- організація руху денних пасажирських поїздів;

- поетапне впровадження швидкісних пасажирських поїздів, насамперед за напрямками Київ - Донецьк, Київ - Харків, Київ - Одеса, Київ -Дніпропетровськ, Київ Львів, Дніпропетровськ - Сімферополь;

- надання державної підтримки у вирішенні питань щодо закупівлі пасажирського рухомого складу, будівництва i реконструкції об'єктів інфраструктури залізниць, що мають соціальне значення.

Усе це призвело до створення Державного підприємства «Українська залізнична швидкісна компанія», яке $є$ новим потужним гравцем на ринку пасажирських перевезень України та першопрохідцем у напрямку розвитку абсолютно нового сегмента пасажирських перевезень - денних швидкісних перевезень. Основними перевагами послуг, які надаються пасажирам поїздами Української залізничної швидкісної компанії, $є$ :

- тривалість подорожі: час подорожі між центрами міст поїздами IHTEPCITI + та IHTEPCITI $\epsilon$ співрозмірним 3 аналогічним i ненабагато більшим, ніж при подорожі літаком;

- вартість перевезень: незважаючи на те, що час подорожі суттєво скорочено, вартість перевезень залишається на рівні, типовому для наземного транспорту;

- доступність для пасажирів: поїздами IHTEPCITI+ та IHTEPCITI вже сьогодні сполучено найбільші міста України, між якими існують найбільші пасажиропотоки;

- точність і надійність: рух поїздів здійснюється за чітко розрахованим графіком. Погодні умови та інші фактори не мають такого значного впливу на дотримання графіка руху, як на інші види транспорту;

- комфорт: подорожі поїздами IHTEPCITI+ та IHTEPCITI $€$ комфортними та зручними для пасажира, що досягається за рахунок сучасного рухомого складу 3 комфортним інтер'єром та ергономікою, а також високого рівня сервісу для пасажирів; 
- зручний розклад руху: розклад руху розроблено 3 урахуванням максимальної кількості потреб пасажирів. Зокрема вдалось уникнути надто пізнього прибуття ранкових поїздів і надто раннього відправлення вечірніх поїздів, що дозволяє пасажирам більш оптимально спланувати свій день;

- сервіс: орієнтований підхід до перевезень.

ДП «Українська залізнична швидкісна компанія» вперше в Україні запроваджує сервіс, орієнтований на здійснення перевезень, який полягає у формуванні комплексного продукту для пасажирів, що зробить подорож швидкою, комфортною та приємною [3].

За період впровадження швидкісного залізничного руху в Україні у внутрішньому сполученні збільшилася кількість їх маршрутів та обсяги перевезень пасажирів. Загалом від початку курсування швидкісних поїздів квитки на них купили 5 млн 895 тис. пасажирів, а квітень 2015 року продемонстрував найвищий показник - 260 тис. подорожувальників обрали поїзди категорії Інтерсіті та Інтерсіті+, які курсують зі швидкістю до 160 км/год.

Переваги поїздів Інтерсіті оцінили не лише громадяни України, а й гості держави. Рівень сервісу постійно адаптується до потреб мандрівників. Зараз територією України курсує 12 пар швидкісних поїздів за напрямками: Київ-Харків, Дарниця - Львів, Дарниця Трускавець, Київ-Дніпропетровськ, Красноармійськ, Київ-Запоріжжя, Київ Костянтинівка, Київ - Кривий Ріг, Дарниця Тернопіль, Дарниця-Одеса. У планах Української залізничної швидкісної компанії та Укрзалізниці - подальший розвиток мережі регулярного швидкісного руху, зокрема розроблення та впровадження нових маршрутів, а також збільшення інтенсивності руху на вже існуючих [5].

Основним завданням роботи залізничного транспорту є повне та своєчасне задоволення потреб населення країни в перевезеннях i наданні послуг. Тому підвищення швидкостей руху пасажирських поїздів - одне 3 найважливіших завдань підвищення рівня обслуговування пасажирів. Удосконалення швидкісного руху полягає не тільки в скороченні часу в дорозі, а й у підвищенні їх комфортності і надання ними послуг [4]. Послуги, які виконуються на залізниці, $є$ різноманітними, і навіть незначні поліпшення надання послуг у результаті можуть дати величезні вигоди. Якщо розглядається швидкісний рух, то необхідно пам'ятати, що обслуговування пасажирів полягає не тільки в їхньому швидкому проїзді, але і в комфортному надані послуг. Одним 3 видів послуг, які надає залізниця, - це зручне переміщення, збереження та відправлення багажу та вантажобагажу за призначенням.

Відправити речі залізницею може будьяка фізична чи юридична особа: обмежень немає. При цьому магістраль здійснює перевезення двох типів вантажів - багажу та вантажобагажу. Багаж оформлюється лише пасажиром за наявності квитка на поїзд, а для транспортування вантажобагажу клієнту не потрібно жодних документів.

Процедура відправлення вантажу:

по-перше, при користуванні багажним відділенням залізниць потрібно переконатись, що речі не підпадають під список заборонених для транспортування;

по-друге, товар повинен бути упакований належним чином. За Правилами перевезення пасажирів, багажу, вантажобагажу та пошти, залізничним транспортом України речі приймаються лише в надійній упаковці, яка забезпечує їх схоронність на всьому шляху прямування до видачі пасажиру.

На місці клієнт заповнює заяву на відправлення вантажобагажу/багажу. Для цього приймальник зважує речі і рахує кількість місць. На основі заяви клієнт у касі оформлює проїзний документ i оплачує перевезення. Оплата за відправку залежить від кілометражу і тоннажу. Отримавши проїзний документ, працівники багажного відділення вантажать речі у вагон чи на склад за допомогою спеціальної техніки. Загалом оформлення займає 15-30 хв залежно від кількості вантажобагажу. Зазвичай користувачі багажного відділення перевозять домашні речі, меблі, дитячі товари, велосипеди тощо.

На залізницях України функціонує 29 багажних відділень. Найбільші 3 них розташовані на вокзалах станцій Дніпропетровськ, Львів, Харків, Івано-Франківськ, Донецьк, Луганськ, Київ, Одеса - Головна. За останні 2 роки було закрито 8 багажних відділень через їх збитковість [1].

Однак при створенні сприятливих умов для користувачів послугами багажного відділення, яке буде функціонувати в поєднанні 
3 послугою транспортування швидкісними поїздами, можливо зробити відправлення вантажобагажу/багажу привабливим. Розширення видів супутніх послуг при відправлення багажу та вантажобагажу, доставка за схемою «від дверей до дверей», привабливі тарифи - напрями, що дозволять зробити даний вид послуги рентабельним.

Висновки. Розвиток ринкових відносин у державі сприяє зростанню i зміцненню економіки, представники цих відносин користуються послугами залізничного транспорту в різних видах пасажирських сполучень. Досвід роботи залізничного транспорту протягом трансформаційного періоду, який розпочався в 1991 році, показує, що зміцнення фінансового стану підрозділів залізниць, які займаються пасажирськими перевезеннями, можливо завдяки більш глибокому урахуванню індивідуальних вимог пасажирів. Це можна здійснити шляхом розширення обсягу послуг, що здійснюються залізницями та надаються пасажирам, а саме комфортне переміщення пасажирів, багажу та вантажобагажу територією України [2].

\section{Список використаних джерел}

1. Багажний «помічник» [Електронний ресурс]: [стаття від 26.05.2015 року]. - Режим доступу: http://magistral-uz.com.ua.

2. Сервіс центри 3 обслуговування пасажирів на залізничному транспорті [Електронний pecypc]:[стаття]. - Режим доступу: http://jrnl.nau.edu.ua.

3. Напрямки впровадження швидкісних пасажирських перевезень в Україні [Електронний pecypc]: [стаття]. - Режим доступу: http://pre.diit.edu.ua.

4. Удосконалення організації пасажирських перевезень в умовах конкуренції [Електронний pecypc]:[стаття]. - Режим доступу: http://vestnik2079-5459.khpi.edu.ua.

5. За 3 роки впровадження швидкісного руху поїздами скористалося майже 5 млн пасажирів [Електронний ресурс]: [стаття]. - Режим доступу: http://magistral-uz.com.ua.

6. Правила перевезення пасажирів, багажу, вантажобагажу та пошти [Електронний ресурс]: наказ Міністерства транспорту та зв'язку України від 27 грудня 2006 р. №1196. - Режим доступу: http://www.kmu.gov.ua.

7. Державна служба статистики України [Електронний ресурс]. - Режим доступу: http://www.ukrstat.gov.ua.

8. Технологія роботи вокзалу [Електронний ресурс]: [дипломна робота]. - Режим доступу: http:// br.com.ua diplom/technical/64385.htm.

9. Впровадження швидкісного руху пасажирських поїздів крок за кроком [Електронний pecypc]: [стаття]. - Режим доступу: http://magistral-uz.com.ua.

10. Стратегія розвитку залізничного транспорту на період до 2020 р. [Електронний ресурс]. Режим доступу: http:// zakon.rada.gov.ua.

Рецензент д-р техн. наук, професор С.С. Альошинський

Обухова Анна Леонідівна, канд. техн. наук, доцент кафедри управління вантажною і комерційною роботою, Український державний університет залізничного транспорту. Тел.: (057) 730-10-85. E-mail: anya.obukhova@gmail.com.

Мар`юшкіна Євгенія Юріївна, магістрант ІППК Тел.: (097) 280-16-68. E-mail: nastya.1411@mail.ru.

Obukhova Anna, Cand. of tehn. science, lecturer department of management of freight and commercial work, Ukraine State University of Railway Transport. Tel.: (057) 730-10-85. E-mail: anya.obukhova@gmail.com. Mariushkina Evgeniya Yurievna master IPPK Tel.: (097) 280-16-68 E-mail: nastya.1411@mail.ru

Наукова праця здана до друку 17.06.2015 року 